DOI: $10.20472 /$ IAC.2018.042.026

\author{
VAIVA JUCEVIČIŪTĖ-BARTKEVIČIENĖ \\ Lithuanian University of Educational Sciences, Lithuania \\ RIČARDAS BARTKEVIČIUS \\ Lithuanian University of Educational Sciences, Lithuania \\ OLEKSANDRA YEHOROVA \\ National Pedagogical Dragomanov University, Ukraine
}

\title{
FOSTERING THE CULTURAL IDENTITY IN NON-FORMAL ART EDUCATION
}

\begin{abstract}
:
Historically, Lithuania is a multicultural country, where many nations - Lithuanians, Jews, Russians, Poles, Ukrainians and others - have beautifully lived together from ancient times. In the face of globalization and migration of nations, a two-way issue arises: how to maintain our own cultural identity and heritage, and how to enrich it, by adopting traditions and customs of other nations. At the same time, it is important to grasp the experience of these issues in neighbouring countries.

The aim of the research - to reveal the approach of young people, who are involved in the artistic activities of non-formal education, towards their cultural identity. This aim dictates research questions: how do young people describe the notion of cultural identity? are they prepared for the integration of cultural heritage of other nations in their artistic activities? what is the extent to which ethnic music and folk art are relevant in the context of their cultural identity today?

The theoretical analysis involved the examination of the scientific literature and documents. The empirical research was carried out using questionnaires and interviews. Qualitative research was conducted in 2015-2018.

The questionnaire survey (with opened questions) was performed in higher education schools in Lithuania, Latvia, Poland and Ukraine in the processes of non-formal activities (clubs for fine art activities, musical ethno-cultural ensembles). The total sample consisted of 43 informants. The qualitative content analysis was applied processing the accumulated data.

Main results show that despite the fact that young people understand very differently the concept of cultural identity, many of them very much appreciate their traditions and ethno-culture. At the same time, they say they want to learn more about other cultures, people of other nations, their art. They highlight the fact, that the multicultural experience and knowledge of ethnic culture makes it possible to be more tolerant for ethnic and cultural differences.
\end{abstract}

\section{Keywords:}

Cultural identity, non-formal education, art education, higher education

JEL Classification: 120, 123, 121 